\title{
A importância do discurso religioso na luta pela redução das desigualdades sociais no Brasil: \\ A influência do pensamento social da Igreja católica na legislação trabalhista brasileira de Vargas a Lula
}

\section{Ulisses Borges de Resende}

Orientador: Profa Dra $\underline{\text { a }}$ Christiane Girard Ferreira Nunes

Curso: Doutorado de Sociologia

Data da Defesa: 4.09.2009

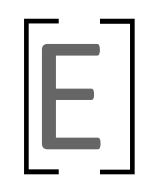

sta pesquisa investiga a influência do pensamento social da Igreja Católica Apostólica Romana na legislação trabalhista brasileira, de Vargas a Lula, em razão das mudanças da geopolítica internacional decorrentes das Primeira e Segunda Guerras Mundiais (1914-1918 e 19391945) e da queda do muro de Berlim (1989). Trata-se de uma pesquisa que utiliza o método qualitativo mediante a análise de conteúdo, cujo objeto empírico está ancorado na avaliação dos documentos que compõem a doutrina social da Igreja e a legislação trabalhista brasileira. Com o advento da Revolução Russa, de 1917, e a consequente criação da Organização Internacional do Trabalho (OIT), em 1919, que desde o início se socorreu dos princípios expostos pelo Papa Leão XIII na encíclica Rerum Novarum, de 1891, o pensamento social da Igreja serviu de fonte de inspiração para as forças exógenas que pressionaram a construção do trabalhismo da Era Vargas no Brasil. Uma abordagem histórica da Igreja Católica Apostólica Romana, desde a sua origem, passando pelo monacato irlandês de São Patrício e pela Revolução Francesa, é utilizada como cenário de fundo da pesquisa, o que propiciou a constatação das suas mudanças, com ênfase nas que decorreram do Concílio Vaticano II (1961-1965). A nova geopolítica internacional que emerge do Consenso de Washington (1989), sob os ventos neoliberais, passa a exercer pressão externa em sentido contrário, agora pela desregulamentação da legislação trabalhista brasileira. Ao longo das duas últimas décadas, vários fatores serviram de resistência às referidas novas pressões exógenas, entre eles a eleição de Lula. Diante das perspectivas e incertezas quanto ao futuro do direito do trabalho no Brasil, cuja retração poderá conduzir à volta das desigualdades sociais experimentadas pela sociedade in- 
dustrial europeia no século XIX, o pensamento social da Igreja assume importância redobrada, com seus princípios de solidariedade e subsidiariedade em prol da valorização da dignidade da pessoa humana, tornando-se fundamental para a defesa da emancipação dos trabalhadores.

Palavras-chave: Pensamento social da Igreja; encíclicas sociais; solidariedade, subsidiariedade e sindicalismo; legislação trabalhista brasileira; Consolidação das Leis do Trabalho. 